\title{
Derajat Toksisitas Hemoglobin pada Penderita Kanker Kolorektal yang Mendapat Kemoterapi CapeOX
}

\author{
Yusmaidi ${ }^{1}$, Jordy Oktobiannobel ${ }^{2}$, Muhammad Nur ${ }^{3}$, Bella Sabila Dananda ${ }^{4 *}$ \\ ${ }^{1}$ Departemen Bedah Digestif Rumah Sakit Abdul Moeloek, yusmaidifathurrahman@gmail.com \\ ${ }^{2}$ Departemen Farmakologi Fakultas Kedokteran Universitas Malahayati, oktobiannobeljordy@ gmail.com \\ ${ }^{3}$ Departemen Patologi Klinik Rumah Sakit Umum Daerah Pringsewu, muhammad.nur40@yahoo.co.id \\ ${ }^{4}$ Program Pendidikan Dokter Fakultas Kedokteran Universitas Malahayati, belladananda13gmail.com
}

\begin{abstract}
ABSTRAK
Kemajuan pengobatan dan penggunaan kemoterapi pada beberapa dekade terakhir menyebabkan perubahan terhadap angka harapan hidup penderita kanker kolorektal. Studi yang dilakukan di China dan Hongkong, menunjukkan regimen kemoterapi kombinasi CapeOX lebih sering digunakan dan hal serupa juga didapatkan di negara-negara di Eropa dan USA. Akan tetapi penggunaan obat kemoterapi yang mengandung oxaliplatin dan capecitabine dapat menimbulkan efek samping berupa toksisitas hematologi yaitu salah satunya anemia. Tujuan dari penelitian ini adalah untuk mengetahui perbedaan berupa penurunan rerata kadar hemoglobin dan derajat toksisitas hemoglobin pada penderita kanker kolorektal yang menjalani kemoterapi CapeOX. Penelitian ini berbentuk hystorical retrospective cohort. Sampel penelitian ini adalah 70 penderita kanker kolorektal yang mendapat kemoterapi CapeOX selama 6 siklus di RSUD Dr. H. Abdul Moeloek tahun 2018-2019. Teknik pengambilan sample menggunakan consecutive sampling. Analisis data menggunakan uji Paired T-Test. Terdapat perbedaan berupa penurunan rerata kadar hemoglobin yang bermakna secara statistik pada penderita kanker kolorektal yang mendapat kemoterapi CapeOX selama 6 siklus dengan p value <0,005. Dan didapatkan peningkatan jumlah penderita yang mengalami toksisitas hemoglobin seiring dengan penambahan siklus kemoterapi. Dimana pada siklus pertama didapatkan 59 penderita $(84,3 \%)$ yang mengalami toksisitas hemoglobin pasca kemoterapi dan jumlahnya terus meningkat hingga 69 penderita (98,6\%) pada siklus keenam. Terdapat penurunan rerata kadar hemoglobin pada penderita kanker kolorektal yang mendapat kemoterapi CapeOX dengan p value <0,05 dan didapatkan peningkatan jumlah penderita yang mengalami toksisitas hemoglobin.
\end{abstract}

Kata Kunci : Kanker Kolorektal, Kemoterapi, Hemoglobin.

\begin{abstract}
Advances in the treatment and use of chemotherapy have been shown to improve the life expectancy rate for colorectal cancer patients. Studies conducted in China and Hongkong have shown that CapeOX combination chemotherapy regimens are more commonly used than in Europe and the United States. However, the use of chemotherapy drugs containing oxaliplatin and capecitabine can cause side effects such as hematological toxicity, which is one of them is anemia. This study aims to determine the difference in the form of a decrease in the average levels of hemoglobin and the degree of hemoglobin toxicity in colorectal cancer patients undergoing CapeOX chemotherapy. The Design in this study is a historical (retrospective) cohort. This study sample was 70 colorectal cancer patients who received CapeOX chemotherapy for 6 cycles at RSUD Dr. H. Abdul Moeloek in 2018-2019. Consecutive sampling is used in the sampling method. The statistical analysis is using Paired T-Test. There is a significant difference in the average hemoglobin level of colorectal cancer patients $(p$-value $=<0.005)$, which receive CapeOX chemotherapy for 6 cycles. Besides, there is an increase in the number of patients who get hemoglobin toxicity and the chemotherapy cycle. In the first cycle, 59 patients (84.3\%) got hemoglobin toxicity after chemotherapy, and the number continued to increase to 69 patients $(98.6 \%)$ in the sixth cycle. There was a decrease in hemoglobin levels in colorectal cancer patients who received CapeOX chemotherapy with p-value $=<0.05$ and increased patients who got hemoglobin toxicity.
\end{abstract}

Keywords: Colorectal cancer, Chemotherapy, Hemoglobin

*Korespondensi Author : Bella Sabila Dananda, Fakultas Kedokteran Universitas Malahayati, belladananda13@gmail.com,089631152599

\section{PENDAHULUAN}

Kanker kolorektal adalah kanker yang terdapat pada kolon dan/atau rektum. Menurut data GLOBOCAN 2018, kanker kolorektal merupakan keganasan ketiga terbanyak serta menjadi penyebab kematian kedua terbanyak di 
dunia. Sedangkan di Indonesia, kanker kolorektal merupakan kanker keempat terbanyak. ${ }^{1}$ Di Provinsi Lampung, khususnya Kota Bandar Lampung juga telah dilakukan penelitian bertempat di Rumah Sakit Umum Daerah (RSUD) Dr. H. Abdul Moeloek yang menunjukkan peningkatan kejadian kanker kolorektal setiap tahunnya. Disebutkan bahwa terdapat 31 kasus pada tahun 2004-2005 dan meningkat menjadi 86 kasus pada tahun 2007-2009. . $^{2,3}$ Tingginya kasus kanker kolorektal disebabkan karena hampir setengah dari pasien terdiagnosis pada tahap lanjutan dan sedikit yang ditemukan pada stadium / staging awal (stadium I atau staging localized) sehingga penanganan sulit dilakukan. ${ }^{4}$

$\begin{array}{cccc}\text { Terapi } & \text { kuratif } & \text { terbaik } & \text { dalam } \\ \text { penatalaksanaan } & \text { kanker } & \text { kolorektal } & \text { adalah }\end{array}$
reseksi bedah, namun dengan rekurensi yang tinggi. ${ }^{5}$ Tingginya angka rekurensi tindakan reseksi pada pasien kanker kolorektal menjadi alasan pentingnya modalitas terapi lain, seperti kemoterapi dan radioterapi. ${ }^{6}$ Kemajuan pengobatan dan penggunaan kemoterapi kombinasi pada beberapa dekade terakhir menyebabkan perubahan terhadap angka harapan hidup penderita kanker kolorektal. Kemoterapi ajuvan merupakan kemoterapi yang diberikan sebagai terapi tambahan atau mengikuti terapi primer yang bertujuan untuk mengeliminasi residu mikroskopis sel kanker untuk menyembuhkan dan menurunkan risiko rekurensi. $^{7}$

Studi yang dilakukan di China dan Hongkong, menunjukkan regimen kemoterapi kombinasi CapeOX (Capecitabine + Oxaliplatin) lebih sering digunakan dibandingkan mFOLFOX7 (5-Fluorourasil + Leucovorin + Oxilaplatin) karena CapeOX memiliki efektivitas yang tidak kalah dibandingkan mFOLFOX7 dan CapeOX tidak memerlukan akses vena sentral dalam pemberiannya. ${ }^{8} \mathrm{Hal}$ serupa didapatkan di negara-negara di Eropa dan USA (United States America) ${ }^{7,9}$.

Efek samping atau toksisitas yang bisa terjadi pada pemberian obat kemoterapi yang mengandung fluorourasil, leucovorin, oxaliplatin, capecitabine dan irinotecan dapat berupa: anemia, leukopenia, neutropenia trombositopenia, mual, muntah, diare, mukositis, alopesia, sindroma kolinergik, neuropati, panas, asthenia, gangguan jantung, gangguan kulit ataupun reaksi hipersensitivitas. ${ }^{2}$ Anemia adalah komplikasi hematologis umum kemoterapi yang dikaitkan dengan peningkatan morbiditas, mortalitas, dan biaya perawatan kesehatan. Agen kemoterapi sitotoksik dapat menginduksi anemia melalui gangguan langsung hematopoiesis, termasuk sintesis prekursor sel darah merah (SDM) di sumsum tulang, mengurangi produksi eritropoietin ginjal, atau kombinasi keduanya. ${ }^{10}$ Studi sebelumnya melaporkan bahwa kejadian anemia dapat berkisar dari $20 \%$ hingga $60 \%$ pada saat diagnosis kanker dan mencapai setinggi $60-90 \%$ selama perawatan kanker berupa kemoterapi. ${ }^{11}$

Berdasarkan latar belakang tersebut, penulis tertarik untuk melakukan penelitian mengenai derajat toksisitas hemoglobin pada penderita kanker kolorektal yang mendapat kemoterapi CapeOX (Capecitabine+Oxaliplatin) di RSUD Dr. H. Abdul Moeloek Bandar Lampung tahun 2018-2019.

\section{METODOLOGI}

Penelitian ini menggunakan jenis penelitian observasional dengan desain penelitian historical (retrospective) cohort yaitu penelitian yang dilakukan pada saat ini dan melihat ke beberapa waktu belakang untuk memeriksa kejadian atau hasil medis. Dengan kata lain, sekelompok subjek yang dipilih berdasarkan status pajanan dipilih pada saat ini, dan data hasil (yaitu status penyakit, status kejadian), yang diukur di masa lalu, direkonstruksi untuk analisis. ${ }^{12}$ Dalam penelitian ini, peneliti memilih kelompok penderita kanker kolorektal yang mendapat kemoterapi CapeOX dan menganalisis apakah terdapat perbedaan berupa penurunan kadar hemoglobin pada penderita yang menjalani kemoterapi CapeOX tersebut. Penelitian ini dilaksanakan di Ruang Raflesia dan Ruang Rekam Medik RSUD Dr.H. Abdul Moeloek pada bulan Februari 2020. Populasi dalam penelitian ini adalah seluruh penderita kanker kolorektal yang mendapat kemoterapi CapeOX 
selama 6 siklus pada tahun 2018-2019 yaitu sebanyak 90 penderita. Lalu sampel pada penelitian ini diambil dengan menggunakan teknik consecutive sampling yaitu sebanyak 70 sampel. Metode pengumpulan data yang digunakan dalam penelitian ini adalah pengumpulan data sekunder yang diperoleh dari data rekam medis untuk melihat kadar hemoglobin pre dan post kemoterapi pada penderita kanker kolorektal yang mendapat kemoterapi CapeOX sepanjang tahun 2018 hingga 2019.

Data penelitian diolah dengan program SPSS dengan menggunakan analisis univariat untuk menjabarkan tabel distribusi usia, jenis kelamin, jenis operasi kemudian dilanjutkan analisis bivariat dengan uji Paired T- Test untuk mengetahui penurunan rerata kadar hemoglobin pre dan post kemoterapi pada penderita kanker kolorektal yang mendapat kemoterapi CapeOX. Pengujian analisis dengan tingkat kesalahan 5\% apabila didapatkan nilai $\mathrm{p} \leq 0,005$ maka Ho ditolak, dan $\mathrm{Ha}$ diterima yaitu terdapat penurunan rerata kadar hemoglobin pre dan post kemoterapi yang bermakna pada penderita kanker kolorektal yang mendapat kemoterapi CapeOX.

\section{HASIL DAN PEMBAHASAN}

Karakteristik penderita pada penelitian ini dijelaskan dalam tabel 1. Berdasarkan tabel, didapatkan frekuensi tertinggi usia penderita yaitu antara 56-65 tahun sebanyak $27(38,6 \%)$ penderita dan frekuensi yang terendah usia penderita yaitu antara 13-25 tahun sebanyak 1 $(1,4 \%)$ penderita. Dan proporsi penderita yang berjenis kelamin laki-laki yaitu sebanyak 36 $(51,4 \%)$ dan yang berjenis kelamin perempuan $34(48,6 \%)$. Lalu, untuk jenis tindakan operasi terbanyak adalah Low Anterior Resection sebanyak $40(57,1 \%)$ penderita.

Tabel 1. Karakteristik Penderita Kanker Kolorektal yang Mendapat Kemoterapi CapeOX di RSUDDr. H. Abdul Moeloek

\begin{tabular}{|c|c|c|}
\hline Karakteristik & Frekuensi & $(\%)$ \\
\hline \multicolumn{3}{|l|}{ Usia (tahun) } \\
\hline $\begin{array}{l}\text { Balita } \\
\quad(0-5)\end{array}$ & 0 & 0 \\
\hline $\begin{array}{l}\text { Kanak-Kanak } \\
(6-12)\end{array}$ & 0 & 0 \\
\hline $\begin{array}{l}\text { Remaja } \\
(13-25)\end{array}$ & 1 & 1,4 \\
\hline $\begin{array}{l}\text { Dewasa } \\
(26-45)\end{array}$ & 22 & 31,4 \\
\hline $\begin{array}{l}\text { Lansia awal } \\
(46-55)\end{array}$ & 15 & 21,4 \\
\hline $\begin{array}{l}\text { Lansia akhir } \\
(56-65)\end{array}$ & 27 & 38,6 \\
\hline $\begin{array}{r}\text { Manula } \\
(>65)\end{array}$ & 5 & 7,1 \\
\hline \multicolumn{3}{|l|}{ Jenis Kelamin } \\
\hline Laki laki & 36 & 51,4 \\
\hline Perempuan & 34 & 48,6 \\
\hline \multicolumn{3}{|l|}{ Jenis Operasi } \\
\hline $\begin{array}{l}\text { Hemikolektomi } \\
\text { kanan }\end{array}$ & 4 & 5,7 \\
\hline Hemikolektomi kiri & 7 & 10,0 \\
\hline Anterior Resection & 0 & 0 \\
\hline $\begin{array}{l}\text { Low Anterior } \\
\text { Resection }\end{array}$ & 40 & 57,1 \\
\hline $\begin{array}{l}\text { Abdominoperineal } \\
\text { Resection }\end{array}$ & 19 & 27,1 \\
\hline
\end{tabular}

Dari tabel 2, dapat diketahui bahwa terdapat perbedaan berupa penurunan rerata kadar hemoglobin pada penderita kanker kolorektal pre dan post kemoterapi CapeOX dari siklus pertama hingga siklus keenam. Hal ini dapat kita lihat pada tabel 4, dimana awal nilai rerata kadar hemoglobin pre kemoterapi sebesar 11.769 dan terus mengalami penurunan hingga 10.954 pada post kemoterapi siklus keenam.
Tabel 2. Nilai Rerata Kadar Hemoglobin Pre Kemoterapi dengan Post Kemoterapi CapeOX Selama 6

Siklus Pada Penderita Kanker 


\begin{tabular}{lll}
\hline & \multicolumn{2}{c}{ Kolorektal di RSUD Dr. H. Abdul } \\
& \multicolumn{2}{c}{ Moeloek } \\
& \multicolumn{2}{c}{ Rerata \pm SD (gr/dL) } \\
\hline & \multicolumn{2}{c}{$11.769 \pm 0.9778$} \\
Siklus 1 & Pre Kemoterapi & $11.673 \pm 0.9721$ \\
& Post Kemoterapi & $11.673 \pm 0.9721$ \\
Siklus 2 & Pre Kemoterapi & $11.544 \pm 0.9276$ \\
& Post Kemoterapi & $11.544 \pm 0.9276$ \\
Siklus 3 & Pre Kemoterapi & 11.544 \\
& Post Kemoterapi & $11.304 \pm 0.8913$ \\
Siklus 4 & Pre Kemoterapi & $11.304 \pm 0.8913$ \\
& Post Kemoterapi & $11.027 \pm 0.9038$ \\
Siklus 5 & Pre Kemoterapi & $11.027 \pm 0.9038$ \\
& Post Kemoterapi & $10.954 \pm 0.9023$ \\
Siklus 6 & Pre Kemoterapi & $10.954 \pm 0.9023$ \\
& Post Kemoterapi & $10.864 \pm 0.8477$ \\
\hline
\end{tabular}

Dari tabel 3, didapatkan perbedaan berupa penurunan kadar hemoglobin yang bermakna secara statistik pasca dilakukan kemoterapi di setiap siklusnya hingga siklus keenam. Terdapat penurunan rerata kadar hemoglobin yang bermakna dengan $\mathrm{p}<0,05$ pada setiap siklus kemoterapi.

\begin{tabular}{lcc}
\hline & $\begin{array}{l}\text { Rerata } \\
(\mathrm{gr} / \mathrm{dL})\end{array}$ & $\pm \mathrm{SD}$ \\
\hline Pre hb1 - Post hb1 & $0,0954 \pm 0,33$ & 0,019 \\
Pre hb2 - Post hb2 & $0,1286 \pm 0,95$ & 0,000 \\
Pre hb3 - Post hb3 & $0,2400 \pm 0,20$ & 0,000 \\
Pre hb4 - Post hb4 & $0,2771 \pm 0,59$ & 0,000 \\
Pre hb5 - Post hb5 & $0,0729 \pm 0,20$ & 0,003 \\
Pre hb6 - Post hb6 & $0,0900 \pm 0,17$ & 0,000 \\
\hline
\end{tabular}

Berdasarkan tabel 4, didapatkan peningkatan jumlah penderita yang mengalami toksisitas hemoglobin derajat 1 dan derajat 2 seiring dengan penambahan siklus kemoterapi. Dimana pada siklus pertama didapatkan 59 $(84,3 \%)$ penderita yang mengalami toksisitas hemoglobin pasca kemoterapi dan jumlahnya terus meningkat hingga $69(98,6 \%)$ penderita pada siklus keenam.

Tabel 4. Insiden Toksisitas Hemoglobin Post Kemoterapi CapeOX Selama 6 siklus pada Penderita Kanker Kolorektal di RSUD Dr. H. Abdul Moeloek

\begin{tabular}{cccccc}
\hline Kemoterapi & \multicolumn{5}{c}{$\begin{array}{c}\text { Derajat toksisitas } \\
\text { hemoglobin }(\mathbf{n}(\%))\end{array}$} \\
\hline & $\mathbf{1}$ & $\mathbf{2}$ & $\mathbf{3}$ & $\mathbf{4}$ & Total \\
\hline Siklus 1 & 59 & 0 & 0 & 0 & 59 \\
& $(84,3)$ & & & & $(84,3)$ \\
Siklus 2 & 62 & 0 & 0 & 0 & 62 \\
& $(88,6)$ & & & & $(88,6)$ \\
Siklus 3 & 64 & 3 & 0 & 0 & 67 \\
& $(91,4)$ & $(4.3)$ & & & $(95,7)$ \\
Siklus 4 & 64 & 4 & 0 & 0 & 68 \\
& $(91,4)$ & $(5,7)$ & & & $(97,1)$ \\
Siklus 5 & 62 & 6 & 0 & 0 & 68 \\
& $(88,6)$ & $(8,6)$ & & & $(97,1)$ \\
Siklus 6 & 62 & 7 & 0 & 0 & 69 \\
& $(88,6)$ & $(10,0)$ & & & $(98,6)$ \\
\hline
\end{tabular}

\section{Karakteristik Responden}

Sampel penelitian ini terdiri dari 70 penderita kanker kolorektal yang mendapatkan terapi kemoterapi dengan regimen CapeOX. Dari keseluruhan sampel didapatkan usia penderita berkisar 18 tahun sampai dengan 73 tahun, dengan didapatkan frekuensi tertinggi usia penderita yaitu antara 56-65 tahun sebanyak $27(38,6 \%)$ penderita. Hal ini sejalan dengan penelitian yang dilakukan oleh Lubis yang mendapatkan hasil penelitian kelompok umur terbanyak yang menderita kanker kolorektal adalah rentang 50-70 tahun yaitu 65,7\%.13 Data tersebut sesuai dengan penelitian El-Shami et al yang menyatakan bahwa angka insidensi kanker kolorektal lebih tinggi pada usia 50 tahun ke atas dibandingkan dengan usia 20-49 tahun. ${ }^{14}$ Sehingga diperlukannya screening untuk orangorang dengan umur $\geq 50$ tahun karena mempunyai risiko tinggi untuk terjadinya kanker kolorektal. Hal ini disebabkan karena pada penuaan terjadi penurunan fungsi sel dan jaringan dalam mempertahankan struktur dan memperbaiki diri sehingga terjadi penumpukan kerusakan sel. Maka dari itu secara bertahap daya tubuh manusia akan menurun, menyebabkan banyaknya terjadi distorsi metabolik sehingga muncul penyakit degeneratif dan age-related disease seperti kanker kolorektal. ${ }^{15}$

Dari hasil penelitian ini, didapatkan data bahwa insidensi kanker kolorektal paling banyak dijumpai pada jenis kelamin laki-laki 36 
orang $(51,4 \%)$, sedangkan pada perempuan yaitu 34 orang $(48,6 \%)$. Hal ini sejalan dengan penelitian yang dilakukan Shamlee, dimana didapatkan proporsi laki-laki lebih tinggi sebesar 52,9\% dibandingkan perempuan $47,1 \% .{ }^{16}$ Demikian juga dengan penelitian yang dilakukan oleh Novia, didapatkan data bahwa insidensi kanker kolorektal paling banyak dijumpai pada jenis kelamin laki-laki yaitu 44 orang $(54,3 \%)$, sedangkan pada perempuan yaitu 37 orang $(45,7 \%) .{ }^{17}$ Menurut penelitian Lin et al, banyaknya kejadian kanker kolorektal pada laki-laki berhubungan dengan tingkat estradiol. ${ }^{18}$ Estradiol dalam jumlah normal berfungsi dalam spermatogenesis dan fertilitas. Namun, jumlah estradiol yang berlebihan menghambat sekresi protein gonadotropin seperti LH (Luteinizing Hormone) yang selanjutnya akan mengurangi sekresi testosterone. Jumlah testosterone yang tinggi terbukti memiliki hubungan dengan berkurangnya risiko kanker kolorektal. Selain itu hal ini dapat pula disebabkan oleh kebiasaan mengonsumsi alkohol, serta merokok yang lebih banyak pada laki laki sehingga mampu memicu terjadinya keganasan pada usus besar. ${ }^{19}$

Dari hasil penelitian ini, didapatkan data bahwa jenis operasi yang paling banyak dilakukan oleh penderita kanker kolorektal adalah jenis operasi Low Anterior Resection (LAR) yaitu sebanyak $40(57,1 \%)$ penderita. Hal ini sejalan dengan penelitian yang dilakukan oleh Shapour et al, dimana operasi yang paling banyak dilakukan oleh 138 penderita kanker kolorektal adalah jenis operasi Low Anterior Resection yaitu sebanyak 96 (70\%) penderita. ${ }^{20}$ Menurut penelitian yang dilakukan Seung et al, Low Anterior Resection adalah jenis operasi yang paling banyak dipilih oleh penderita kanker kolorektal khususnya penderita kanker rektal karena memiliki overall reccurence sebesar $27 \%$ dimana ini lebih rendah dibandingkan overall recurrence pada APR (Abdomino Pereneal Resection) yaitu sebesar $37 \% .^{21}$

\section{Perbedaan rerata kadar hemoglobin pada penderita kanker kolorektal post kemoterapi.}

Pada penelitian ini didapatkan perbedaan berupa penurunan kadar hemoglobin yang bermakna secara statistik pasca dilakukan kemoterapi. Terdapat penurunan rerata kadar hemoglobin yang bermakna dengan $\mathrm{p}<0,05$ pada setiap siklus kemoterapi. Dalam penelitian ini terlihat adanya penurunan rerata nilai kadar hemoglobin pada pasien kanker kolorektal yang menjalani kemoterapi dari nilai awal sebelum dilakukannya kemoterapi. Hal ini sejalan dengan penelitian yang dilakukan oleh Hairong $\mathrm{Xu}$ et al, dimana terjadi penurunan rerata nilai kadar hemoglobin di setiap siklusnya hingga siklus kelima ataupun keenam. ${ }^{11}$ Akan tetapi, pada penelitian tersebut hanya pasien yang mengalami anemia sedang atau berat yang diamati, sedangkan pada penelitian ini semua pasien yang mengalami anemia ringan, sedang atau berat semua diteliti.

Risiko penurunan rerata nilai kadar hemoglobin dari waktu ke waktu juga karena akumulasi efek myelosupresif agen sitotoksik selama siklus terapi yang berulang. ${ }^{11}$ Obat sitostika salah satunya Oxaliplatin yang digunakan untuk menghambat pertumbuhan sel-sel kanker dapat menekan sumsum tulang. Akibat desakan sumsum tulang akan terjadi pengurangan jumlah stem cell dan kesalahan pada stem cells sisanya yang membuat tidak sanggup membelah dan berdiferensiasi cukup untuk menempati kembali sumsum tulang. Obat sitostika seperti capecitabine di eksresikan dalam bentuk $\alpha$-fluoro- $\beta$-alanine (FBAL) melalui urine oleh ginjal. ${ }^{22}$ Karna sifat obat nya yang bersifat toksik maka dapat menyebabkan nefrotoksisitas. Ketika nefrotoksisitas terjadi akan menyebabkan ginjal mengalami penurunan fungsi. Salah satu fungsi ginjal adalah memproduksi hormon eritropoetin. Ginjal mempunyai fungsi memonitor level oksigenisasi darah untuk merangsang produksi eritropoetin. Ketika ginjal mengalami penurunan maka produksi eritropoetin akan berkurang. Sehingga ketika eritropoetin berkurang maka hematopoesis di sumsung 
tulang akan terganggu karena eritropoetin berfungsi untuk merangsang proliferasi dan pematangan eritroid dan produksi sel darah merah akan berkurang dan menyebabkan anemia. $^{10}$

\section{Derajat toksisitas hemoglobin pada penderita kanker kolorektal post kemoterapi}

Pada penelitian ini didapatkan peningkatan jumlah penderita yang mengalami toksisitas hemoglobin seiring dengan penambahan siklus kemoterapi. Dimana pada siklus pertama didapatkan $59(84,3 \%)$ penderita yang mengalami toksisitas hemoglobin pasca kemoterapi dan jumlahnya terus meningkat hingga $69 \quad(98,6 \%)$ penderita pada siklus keenam. Peningkatan derajat toksisitas anemia 2-3 juga dihubungkan dengan penambahan siklus kemoterapi. ${ }^{23}$ Hal tersebut terlihat pada tabel 6 yaitu terjadi peningkatan jumlah penderita yang mengalami toksisitas hemoglobin derajat 2 pada seri ketiga sebanyak $3(4,3 \%)$ penderita dan terus meningkat hingga 7 $(10,0 \%)$ penderita pada seri keenam. Peningkatan jumlah dan derajat toksisitas hemoglobin seiring penambahan siklus kemoterapi pada penderita kanker kolorektal ini disebabkan karena agen kemoterapi sitotoksik menginduksi anemia melalui gangguan langsung hematopoiesis, termasuk sintesis prekursor sel darah merah (SDM) di sumsum tulang, serta mengurangi produksi eritopoietin oleh ginjal, atau kombinasi keduanya. ${ }^{10}$ Obat sitostika yang digunakan untuk menghambat pertumbuhan sel-sel kanker dapat menekan sumsum tulang. Akibat desakan sumsum tulang akan terjadi pengurangan jumlah stem cell dan kesalahan pada stem cells sisanya yang membuat tidak sanggup membelah dan berdiferensiasi cukup untuk menempati kembali sumsum tulang. Obat sitostika seperti capecitabine di eksresikan dalam bentuk $\alpha$ fluoro- $\beta$-alanine (FBAL) melalui urine oleh ginjal. ${ }^{22}$ Karna sifat obat nya yang bersifat toksik maka dapat menyebabkan nefrotoksisitas. Ketika nefrotoksisitas terjadi akan menyebabkan ginjal mengalami penurunan fungsi. Salah satu fungsi ginjal adalah memproduksi hormon eritropoetin. Ginjal mempunyai fungsi memonitor level oksigenisasi darah untuk merangsang produksi eritropoetin. Ketika ginjal mengalami penurunan maka produksi eritropoetin akan berkurang. Sehingga ketika eritropoetin berkurang maka hematopoesis di sumsung tulang akan terganggu karena eritropoetin berfungsi untuk merangsang proliferasi dan pematangan eritroid dan produksi sel darah merah akan berkurang dan menyebabkan anemia. $^{10}$

\section{SIMPULAN DAN SARAN}

Berdasarkan hasil penelitian dan pembahasan, maka dapat diambil kesimpulan yaitu terdapat perbedaan berupa penurunan rerata kadar hemoglobin pada penderita kanker kolorektal yang mendapat kemoterapi CapeOX selama 6 siklus yang bermakna secara statistik dengan $\mathrm{p}<0,005$ dan didapatkan peningkatan jumlah penderita yang mengalami toksisitas hemoglobin seiring penambahan siklus kemoterapi.

Untuk RSUD Dr. H. Abdul Moeloek perlu dilakukan pemilihan regimen kemoterapi yang tepat terhadap pasien kanker kolorektal yang mendapat kemoterapi agar meminimalisirkan penurunan kadar hemoglobin pada pasien kanker kolorektal yang mendapat kemoterapi. Dan bagi peneliti lainnya perlu dilakukan penelitian lebih lanjut terkait analisis efek samping dari penggunaan kemoterapi selain kemoterapi CapeOX sehingga dapat diketahui secara pasti obat kemoterapi mana yang memiliki efek samping paling kecil terhadap penurunan kadar hemoglobin pada penderita kanker kolorektal yang mendapat kemoterapi sehingga pada saatnya dapat bermanfaat dalam meningkatkan pengetahuan di bidang ilmu kemoterapi khususnya untuk kanker kolorektal.

\section{UCAPAN TERIMA KASIH}

Peneliti juga mengucapkan terima kasih kepada semua pihak yang berperan dalam 
pelaksanaan penelitian ini, terutama kepada RSUD Dr. H. Abdul Moeloek yang telah mendukung pelaksanaan penelitian.

\section{REFERENSI}

1. Ferlay J, Colombet M, Soerjomataram I, Mathers C, Parkin DM, Piñeros M, et al. Estimating the global cancer incidence and mortality in 2018: GLOBOCAN sources and methods. International journal of cancer. 2019;144(8):1941-53.

2. Sari MI, Wahid I, Suchitra A. Kemoterapi Adjuvan pada Kanker Kolorektal. Jurnal Kesehatan Andalas. 2019;8(1S):51-7.

3. Haq AM, Zuraida R, Harun Y. Hubungan Asupan Makan (Serat dan Lemak) dengan Kejadian Karsinoma Kolorektal di RSUD Dr. H. Abdul Moeloek Bandar Lampung. Jurnal Majority. 2014;3(5):53-62.

4. Carrato A. Adjuvant treatment of colorectal cancer. Gastrointestinal cancer research: GCR. 2008;2(4 Suppl 2):S42.

5. Ryuk JP, Choi GS, Park JS, Kim HJ, Park SY, Yoon GS, et al. Predictive factors and the prognosis of recurrence of colorectal cancer within 2 years after curative resection. Ann Surg Treat Res. 2014;86(3):143-51.

6. Shead D, Hanisch L, Vidic E, Clarke R, Corrigan A. Colon Cancer NCCN Guidelines for Patients. Natiinal Compr Cancer Netw. 2018;86:1-33.

7. Schmoll HJ, Van Cutsem E, Stein AE, Valentini V, Glimelius B, Haustermans K, et al. ESMO Consensus Guidelines for management of patients with colon and rectal cancer. a personalized approach to clinical decision making. Annals of oncology. 2012;23(10):2479516.

8. Fernando J, Jones R. The principles of cancer treatment by chemotherapy. Surgery (Oxford). 2015:33(3):131-5.

9. Twelves C, Scheithauer W, McKendrick J, Seitz JF, Van Hazel G, Wong A, et al. Capecitabine versus 5-fluorouracil/folinic acid as adjuvant therapy for stage III colon cancer: final results from the X-ACT trial with analysis by age and preliminary evidence of a pharmacodynamic marker of efficacy. Annals of oncology. $2012: 23(5): 1190-7$.

10. Rodgers GM, Becker PS, Blinder M, Cella D, Chanan-Khan A, Cleeland C, et al. Cancer-and chemotherapy-induced anemia. Journal of the
National Comprehensive Cancer Network. 2012;10(5):628-53.

11. Xu H, Xu L, Page JH, Cannavale K, Sattayapiwat O, Rodriguez R. Incidence of anemia in patients diagnosed with solid tumors receiving chemotherapy, 2010-2013. Clin Epidemiol. 2016; 8: 61-71.

12. Hulley SB, Cummings SR, Browner WS, et al. Designing Clinical Research: An Epidemiologic Approach. 2nd Ed Lippincott Williams \& Wilkins; Philadelphia: 2001. pp. 1336

13.Lubis ND. Profil Penderita Karsinoma Kolorektal Di RSUP H. Adam Malik Medan Pada Tahun 2009-2012[Tugas Akhir]. Medan: Univ Sumatera Utara; 2014.

14.El-Shami K, Oeffinger KC, Erb NL, Willis A, Bretsch JK, Pratt-Chapman ML, et al. American Cancer Society Colorectal Cancer Survivorship Care Guidelines. CA Cancer J Clin. 2015;65(6):427-55

15. Boedhi-Darmojo R. Teori proses menua. Dalam: Martono H, Pranarka K (editor). Buku ajar Boedhi-Darmojo geriatri (ilmu kesehatan usia lanjut). Edisi ke-4. Jakarta: Badan Penerbit FKUI; 2009:3-13

16. Sujenoren S. Prevalensi Anemia pada Pasien Kanker Kolorektal di RSUP Haji Adam Malik Medan [Tugas Akhir]. Medan: Univ Sumatera Utara;2015.

17. Nasution N. Karakteristik Pasien Kanker Kolorektal di RSUP H. Adam Malik Medan 2015-2017[Tugas Akhir]. Medan: Univ Sumatera Utara;2018.

18. Lin JH, Zhang SM, Rexrode KM, Manson JAE, Chan AT, Wu K, et al. Association between sex hormones and colorectal cancer risk in men and women. Clin Gastroenterol Hepatol. 2013;11(4):419-24.

19. Kwon HJ, Kim HJ, Park YS, Lim JH, Park KJ, Shin CM, et al. Body Mass Index as a Predictor of Advanced Colorectal Neoplasia. J Cancer Prev. 2013;18(2):144-8.

20. Omidvari S, Hamedi SH, Mohammadianpanah M, Razzaghi S, Mosalaei A, Ahmadloo N, et al. Comparison of abdominoperineal resection and low anterior resection in lower and middle rectal cancer. J Egypt Natl Canc Inst [Internet]. 2013;25(3):151-60. Available from: http://dx.doi.org/10.1016/j.jnci.2013.06.001. 
21. Yeom SS, Park IJ, Jung SW, Oh SH, Lee JL, Yoon YS, et al. Outcomes of patients with abdominoperineal resection (APR) and low anterior resection (LAR) who had very low rectal cancer. Med(Unites States). 2017;96(43):1-6.

22. Genentech USA, inc. XELODA (Capecitabine) tablets, for oral use. XELODA. 2015; 1-46.

23. Barrett-Lee P, Bokemeyer C, Gascon P, Nortier JW, Schneider M, Schrijvers D, Van Belle S. Management of cancer-related anemia in patients with breast or gynecologic cancer: new insights based on results from the European Cancer Anemia Survey. The oncologist. 2005;10(9):74357. 